\title{
Characterization of Cylindrocarpon Species Associated with Black Foot Disease of Grapevine in Spain
}

\author{
S. Alaniz, M. León, A. Vicent, J. García-Jiménez, P. Abad-Campos, and J. Armengol, Instituto Agroforestal \\ Mediterráneo, Universidad Politécnica de Valencia, Camino de Vera s/n, 46022-Valencia, Spain
}

\begin{abstract}
Alaniz, S., León, M., Vicent, A., García-Jiménez, J., Abad-Campos, P., and Armengol, J. 2007. Characterization of Cylindrocarpon species associated with black foot disease of grapevine in Spain. Plant Dis. 91:1187-1193.

In this work, 82 Cylindrocarpon isolates associated with black foot disease of grapevines in Spain were studied by means of phenotypical characterization, DNA analyses, and pathogenicity tests. Partial sequences of the beta-tubulin (BT) gene, BT1, were amplified using primers BT1a and BT1b. A unique and conserved 52-bp insertion in the BT1 sequence, which is a specific marker for C. macrodidymum, was found in 56 of the isolates. The rest of the isolates (26) were identified as $C$. liriodendri. The BT phylogeny grouped all the isolates of each species into two well-supported clades. Phenotypical data were subjected to multivariate factorial analysis. According to this study, the isolates were clearly separated into two groups which were in agreement with BT species identification. C. macrodidymum isolates were differentiated from $C$. liriodendri by producing fewer conidia, presenting longer and wider macroconidia, and lower growth rate at 5 and $10^{\circ} \mathrm{C}$. Selected isolates of each species inoculated onto rooted cuttings of grapevine rootstock cv. $110 \mathrm{R}$ caused typical black foot disease symptoms. This is the first report of C. liriodendri and C. macrodidymum causing black foot disease of grapevines in Spain.
\end{abstract}

Additional keywords: grapevine nurseries, Vitis, young vineyards

Over the last decade, the incidence of fungal grapevine trunk diseases has increased significantly in the different grapevine production areas around the world, particularly in grapevine nurseries and young vineyards. Consequently, there is a renewed interest in the research about these diseases and their causal agents; among them, black foot disease of grapevines caused by Cylindrocarpon spp. (13).

Vines affected by Cylindrocarpon spp. show sunken necrotic root lesions with a reduction in root biomass and root hairs. Removal of rootstock bark reveals black discoloration and necrosis of wood tissues which develops from the base of the rootstock. Other symptoms include reduced vigor, shortened internodes, sparse foliage, and small leaves with interveinal chlorosis and necrosis, frequently leading to death of the plants $(11,13,19,25,29)$. Characteristic black discoloration of affected rootstocks has given the disease the name of black foot $(12,19)$.

Two species of Cylindrocarpon had traditionally been reported as the causal agents of black foot disease of grapevines:

\section{Corresponding author: J. Armengol \\ E-mail: jarmengo@eaf.upv.es}

Accepted for publication 23 April 2007.

doi:10.1094/PDIS-91-9-1187

(C) 2007 The American Phytopathological Society
C. destructans (Zinssmeister) Scholten and C. obtusisporum (Cooke \& Harkn.) Wollenweb. C. destructans was first reported on grapevine in France in 1961 (19), and since then, it was isolated from diseased vines in Italy (11), Portugal (25), Argentina (9), Germany (7), New Zealand (14), South Africa (14), and Brazil (8). C. obtusisporum was identified as the causal agent of this disease in Sicily (12) and in California (29).

In 2004, Halleen et al. (14) characterized phylogenetically a collection of $\mathrm{Cyl}$ indrocarpon isolates obtained from grapevine plants in South Africa, New Zealand, Australia, and France, and described a new species: C. macrodidymum Halleen, Schroers, \& Crous. Later, this species was reported in California (22) and Chile (3). Recently, Halleen et al. (15) compared $C$. destructans isolates obtained from diseased grapevines and other herbaceous and woody hosts with other species in the genus Cylindrocarpon. The results revealed that the French, Portuguese, and South African grapevine isolates previously identified as $C$. destructans or $C$. liriodendri J.D. MacDonald \& E.E. Butler had identical morphological characters, internal transcribed spacer (ITS), and partial betatubulin (BT) gene sequences. C. lirioden$d r i$ was first reported associated with root rot of tulip poplar (Liriodendron tulipifera L.) (18); consequently, Halleen et al. (15) proposed that all $C$. destructans isolates from grapevine included in this study must be reidentified as $C$. liriodendri. Petit and Gubler (23) reached the same conclusion in relation to $C$. destructans isolates from California.

Cylindrocarpon spp. also have been isolated from young declining vines with basal rot or root necrosis in several grapevine-growing countries such as Spain, Greece, or Australia $(1,6,26)$, but to date, no taxonomic studies have been conducted in these countries to further identify the species present.

In Spain, surveys carried out in recent years in grapevine nurseries and young vineyards have confirmed the importance of Cylindrocarpon spp. affecting this crop. These pathogens were found in grapevine nurseries very early in the planting material production process, in grapevine plants ready to be planted and in young vineyards showing decline symptoms. In all cases, Cylindrocarpon spp. were mostly isolated from rootstocks, especially from the basal end $(2,10)$.

The objective of this study was to identify the species of Cylindrocarpon causing black foot disease of grapevine in Spain. In order to do this, isolates from grapevines representative of different locations in Spain were studied by means of phenotypical characterization, DNA analyses, and pathogenicity tests.

\section{MATERIALS AND METHODS}

Fungal isolates. In this study we used 82 Cylindrocarpon isolates representative of different locations and scion/rootstock combinations, obtained from grapevine nurseries and young vineyards in Spain between 2001 and 2004. Additionally, reference isolates of the species C. liriodendri (CBS 117640, CBS 117526, Cy 13 Portugal, and Cy 15 Portugal) and C. macrodidymum (CBS 112609) were obtained from the collection of the Centraalbureau voor Schimmelcultures in Utrecht, the Netherlands (CBS), and from Portugal provided by $\mathrm{C}$. Rego (Laboratório de $\mathrm{Pa}$ tologia Vegetal "Veríssimo de Almeida", Lisboa, Portugal) (Table 1).

Isolates were recovered from roots and the basal end of rootstocks from grapevines exhibiting symptoms of black foot. Sections were cut from affected areas, washed under running tap water, surfacedisinfested for $1 \mathrm{~min}$ in a $1.5 \%$ sodium hypochlorite solution, and washed twice with sterile distilled water. Small pieces of discolored tissues were plated on malt 
extract agar (MEA) (Oxoid Ltd., Basingstoke, Hants, England) supplemented with $0.5 \mathrm{~g} \mathrm{liter}{ }^{-1}$ of streptomycin sulfate (Sigma-Aldrich, St. Louis, MO, USA) (MEAS). Plates were incubated for 5 to 10 days at $25^{\circ} \mathrm{C}$ in the dark. Isolates were transferred to potato dextrose agar (PDA) (Biokar-Diagnostics, Zac de Ther, France), incubated as previously described, and identified as Cylindrocarpon spp. based on colony morphology and conidial characteristics $(4,28)$.

The isolates were single-spored prior to use by means of the serial dilution method (5) and stored in $15 \%$ glycerol solution at $-80^{\circ} \mathrm{C}$ in $1.5-\mathrm{ml}$ cryovials.

Phenotypical characterization. All Cylindrocarpon isolates were grown at $25^{\circ} \mathrm{C}$ in darkness or under NUV + fluorescent illumination with a 12-h photoperiod (Philips TLD18W/33) for 10 days. Media used were PDA and Spezieller Nährstoffarmer agar (SNA) with the addition of $1 \times$ $1 \mathrm{~cm}$ piece of filter paper to the colony surface. Macroscopic characters such as colony texture, color, and the type of growing margin were evaluated on PDA. Colonies grown on PDA were further incubated during 20 days to determine the presence/absence of chlamydospores. The diameter of 20 chlamydospores per isolate was measured. Length and width of 50 conidia (microconidia and one-, two-, and three-septate macroconidia) per isolate were measured on SNA at $\times 400$ magnification. Reverse colony color was determined as described by Petit and Gubler (22); for this, all isolates were grown at $25^{\circ} \mathrm{C}$ for 6 days in the light conditions described above on $2 \%$ MEA (Difco, Sparks, MD, USA).

To determine the effect of temperature on radial colony growth, all isolates were maintained and grown on PDA plates at $25^{\circ} \mathrm{C}$. Plugs of agar, $5 \mathrm{~mm}$ in diameter, were cut from the leading edge of 7-dayold colonies and placed in the center of PDA plates that were then incubated in the dark at $5,10,15,20,25,30$, and $35^{\circ} \mathrm{C}$. There were four replicates for each isolate and temperature combination. After 10 days, colony diameter was measured along two perpendicular axes, and data were converted to radial growth in millimeters per day. The experiment was repeated twice.

The number of conidia produced on mycelia from agar plugs was measured following the method described by Whiting et al. (31). Each isolate was grown on four PDA plates and incubated in darkness at $25^{\circ} \mathrm{C}$. After 7 days of incubation, two plugs of agar with mycelia and spores, 4 $\mathrm{mm}$ diameter, were cut from the growing

Table 1. Cylindrocarpon isolates studied

\begin{tabular}{|c|c|c|c|c|}
\hline \multirow{2}{*}{$\begin{array}{l}\text { Species }^{\mathrm{x}} \\
\text { Isolate }^{\mathrm{y}}\end{array}$} & \multirow[b]{2}{*}{ Year } & \multicolumn{2}{|c|}{ Geographical origin } & \multirow[b]{2}{*}{ Scion/rootstock } \\
\hline & & Town $^{z}$ & Province & \\
\hline \multicolumn{5}{|l|}{ C. liriodendri } \\
\hline Cy 18 & 2002 & Daimiel & Ciudad Real & Tempranillo/110 R \\
\hline Су 21 & 2002 & Lardero & La Rioja & Tempranillo/110 R \\
\hline Cy 23 & 2002 & Campo de Criptana & Ciudad Real & Cencibel/110 R \\
\hline Су 36 & 2002 & Iniesta & Cuenca & Cencibel/1103 P \\
\hline Су 37 & 2002 & Villanueva de Alcardete & Toledo & Cencibel/110 R \\
\hline Су 38 & 2002 & Villanueva de Alcardete & Toledo & Cencibel/110 R \\
\hline Су 39 & 2002 & Herencia & Ciudad Real & Tempranillo/110 R \\
\hline Cy 58 & 2003 & Cózar & Ciudad Real & Cencibel/110 R \\
\hline Су 59 & 2003 & Tarazona & Albacete & Cencibel/1103 P \\
\hline Cy 64 & 2003 & Badajoz & Badajoz & Pardino/n/d \\
\hline Су 66 & 2003 & Villarobledo & Albacete & Cencibel/110 R \\
\hline Су 67 & 2003 & Tarazola & Albacete & Tempranillo/110 R \\
\hline Cу 69 & 2003 & Almaguer & Toledo & Tempranillo/41-B M \\
\hline Су 72 & 2003 & Xàtiva & Valencia & Monastrel1/110 R \\
\hline Cy 80 & 2003 & Aielo de Malferit & Valencia & $\mathrm{n} / \mathrm{d}$ \\
\hline Сy 85 & 2003 & Fontanares & Valencia & Tempranillo/161-49 C \\
\hline Cy 87 & 2004 & Aielo de Malferit & Valencia & Macabeo/110 R \\
\hline Су 88 & 2004 & Aielo de Malferit & Valencia & Macabeo/110 R \\
\hline Cy 89 & 2004 & Aielo de Malferit & Valencia & Garnacha/110 R \\
\hline Су 90 & 2004 & Aielo de Malferit & Valencia & Garnacha/110 R \\
\hline Су 91 & 2004 & Tarazona de la Mancha & Albacete & Cabernet /1103 P \\
\hline Су 93 & 2004 & Villamayor de Santiago & Cuenca & Cencibel/110 R \\
\hline Су 94 & 2004 & Calzada de Calatrava & Ciudad Real & Tempranillo/110 R \\
\hline Cy 97 & 2004 & Haro & La Rioja & Tempranillo/110 R \\
\hline Су 99 & 2004 & Monóvar & Alicante & Syrah/1103 P \\
\hline Су 100 & 2004 & Alesanco & La Rioja & Garnacha/110 R \\
\hline Cy 13 Portugal & 1995 & Por & & $99 \mathrm{R}$ \\
\hline Cy 15 Portugal & 1995 & Por & & $99 \mathrm{R}$ \\
\hline CBS 117640 & 1992 & Por & & Seara Nova /99 R \\
\hline CBS 117526 & 1999 & Por & & $99 \mathrm{R}$ \\
\hline C. macrodidymum & & & & \\
\hline Cy 1 & 2001 & $\mathrm{n} / \mathrm{d}$ & Alicante & Aledo/1103 P \\
\hline Cу 2 & 2001 & Autol & La Rioja & Tempranillo/110 R \\
\hline Cy 3 & 2001 & Autol & La Rioja & Tempranillo/110 R \\
\hline Cy 9 & 2001 & L'Alcudia & Valencia & $\mathrm{n} / \mathrm{d}$ \\
\hline Cy 12 & 2002 & Villafranca de Caballeros & Toledo & Cencibel/110 R \\
\hline Cy 14 & 2002 & $\mathrm{n} / \mathrm{d}$ & Burgos & Tempranillo/110 R \\
\hline Cy 15 & 2002 & $\mathrm{n} / \mathrm{d}$ & Ciudad Real & Tempranillo/110 R \\
\hline Су 16 & 2002 & $\mathrm{n} / \mathrm{d}$ & Ciudad Real & Tempranillo/110 R \\
\hline Cy 17 & 2002 & La Solana & Ciudad Real & Tempranillo/1103 P \\
\hline Cy 19 & 2002 & Villarubia de los Ojos & Ciudad Real & Tempranillo/110 R \\
\hline & & & & (continued on next page) \\
\hline
\end{tabular}

${ }^{\mathrm{x}}$ Species of Spanish isolates were determined by means of beta-tubulin analysis and multivariate factorial analysis of phenotypical data.

y Reference isolates of the species $C$. liriodendri (CBS117640, CBS 117526, Cy 13 Portugal, and $C y$ 15 Portugal) and $C$. macrodidymum (CBS 112609) were obtained from the collection of the Centraalbureau voor Schimmelcultures in Utrecht, the Netherlands (CBS), and from Portugal provided by C. Rego (Laboratório de Patologia Vegetal "Veríssimo de Almeida" Lisboa, Portugal).

${ }^{\mathrm{z}} \mathrm{n} / \mathrm{d}$ : not determined. 
edge of the colonies, and each was placed in a $1.5-\mathrm{ml}$ Eppendorf vial containing $1 \mathrm{ml}$ of sterile water. Vials with plugs were vortexed $5 \mathrm{~s}$, and the number of conidia per $\mathrm{ml}$ was counted using a hemacytometer. The experiment was repeated twice.

Phenotypical data were analyzed by multivariate factorial analysis (21) using the Statgraphics Plus 5.1 software (Manugistics Inc., Rockville, MD, USA). Sixteen variables were included in this analysis: mean length and width of microconidia and one-, two-, and three-septate macroconidia, mean chlamydospore diameter, mean daily growth rate at all temperatures studied, and mean $\log _{10}$ of conidia per ml.

DNA extraction, polymerase chain reaction (PCR), sequencing, and BT phylogeny. Fungal mycelium and conidia from pure cultures grown on PDA for 2 weeks at $25^{\circ} \mathrm{C}$ in the dark were scraped and me- chanically disrupted by grinding to a fine powder under liquid nitrogen using a mortar and pestle. Total DNA was extracted using the E.Z.N.A. Plant Miniprep Kit (Omega Bio-tek, USA) following the manufacturer's instructions. DNA was visualized on $0.7 \%$ agarose gels stained with ethidium bromide and was stored at $-20^{\circ} \mathrm{C}$.

The specific primers Dest1 and Dest4 for C. destructans, which amplify one region of the ITS (16), were used for direct PCR amplification as described by Nascimento et al. (20). In addition, partial sequences of the BT gene, BT1, were amplified using primers BT1a and BT1b (22). Each PCR reaction contained 1× PCR buffer, $2.5 \mu \mathrm{mM} \mathrm{MgCl}_{2}, 200 \mu \mathrm{M}$ each $\mathrm{dNTP}, 0.4 \mu \mathrm{M}$ of each primer, $1 \mathrm{U}$ of DNA Taq polymerase (Dominion MBL, Córdoba, Spain), and $1 \mu \mathrm{l}$ of template DNA.
The PCR reaction mix was adjusted to a final volume of $25 \mu \mathrm{l}$ with water (Chromasolv Plus, Sigma-Aldrich, Steinheim, Germany). PCR amplifications were performed on a Peltier Thermal Cycler-200 (MJ Research). The program consisted of an initial step of $4 \mathrm{~min}$ at $94^{\circ} \mathrm{C}$, followed by 30 cycles ( 35 cycles for BT) of denaturation at $94^{\circ} \mathrm{C}$ for $1 \mathrm{~min}$, annealing at $58^{\circ} \mathrm{C}$ for 1 min, and an elongation at $72^{\circ} \mathrm{C}$ for $1.5 \mathrm{~min}$. A final extension was performed at $72^{\circ} \mathrm{C}$ for $10 \mathrm{~min}$. The PCR products were visualized in $1.5 \%$ agarose gels (agarose D-1 Low EEO, Conda, Madrid, Spain). A 100-bp ladder was used as a molecular weight marker (Dominion MBL).

PCR products of BT1 were purified with the High Pure PCR Product Purification Kit (Roche Diagnostics, Germany) and sequenced in both directions by the DNA Sequencing Service of the Universidad

Table 1. (continued from previous page)

\begin{tabular}{|c|c|c|c|c|}
\hline \multirow{2}{*}{$\begin{array}{l}\text { Species }^{\mathrm{x}} \\
\text { Isolate }^{\mathrm{y}}\end{array}$} & \multirow[b]{2}{*}{ Year } & \multicolumn{2}{|c|}{ Geographical origin } & \multirow[b]{2}{*}{ Scion/rootstock } \\
\hline & & $\operatorname{Town}^{\mathrm{z}}$ & Province & \\
\hline \multicolumn{5}{|c|}{ C. macrodidymum (continued) } \\
\hline Су 22 & 2002 & Tomelloso & Ciudad Real & Tempranillo/140 Ru \\
\hline Cy 25 & 2002 & $\mathrm{n} / \mathrm{d}$ & Murcia & $\mathrm{n} / \mathrm{d}$ \\
\hline Су 28 & 2002 & Monóvar & Alicante & Monastrell/n/d \\
\hline Cy 29 & 2002 & Monóvar & Alicante & Monastrell/n/d \\
\hline Cy 32 & 2002 & Daimiel & Ciudad Real & $\mathrm{n} / \mathrm{d}$ \\
\hline Cy 33 & 2002 & Daimiel & Ciudad Real & $\mathrm{n} / \mathrm{d}$ \\
\hline Сy 34 & 2002 & Granja de Iniesta & Cuenca & Cabernet Sauvignon/110 R \\
\hline Су 40 & 2002 & Carrión de Calatrava & Ciudad Real & Cencibel/110 R \\
\hline Cy 41 & 2002 & Carrión de Calatrava & Ciudad Real & Cencibel/110 R \\
\hline Сy 42 & 2002 & Villar & Valencia & Garnacha/161-49 C \\
\hline Cy 43 & 2002 & Ejea de los Caballeros & Zaragoza & $\mathrm{n} / \mathrm{d}$ \\
\hline Cy 45 & 2002 & Herencia & Ciudad Real & Tempranillo/110 R \\
\hline Сy 47 & 2003 & Mollina & Málaga & Pedro Ximénez/1103 P \\
\hline Cy 48 & 2003 & Mollina & Málaga & Pedro Ximénez/140 Ru \\
\hline Сy 49 & 2003 & Mollina & Málaga & Pedro Ximénez/140 Ru \\
\hline Cy 57 & 2003 & Mollina & Málaga & Cabernet Franc/n/d \\
\hline Сy 60 & 2003 & Campo de Criptana & Ciudad Real & Tempranillo/n/d \\
\hline Сy 61 & 2003 & Pozuelo de Calatrava & Ciudad Real & Tempranillo/161-49 C \\
\hline Сy 62 & 2003 & Quero & Toledo & Tempranillo/110 R \\
\hline Cy 63 & 2003 & Daimiel & Ciudad Real & Cencibel/110 R \\
\hline Cy 65 & 2003 & Membrilla & Ciudad Real & Cencibel/110 R \\
\hline Cy 68 & 2003 & Almaguer & Toledo & Tempranillo/41-B M \\
\hline Cy 70 & 2003 & Quero & Toledo & $161-49 \mathrm{C}$ \\
\hline Cy 71 & 2003 & Beniganim & Valencia & $161-49 \mathrm{C}$ \\
\hline Cy 73 & 2003 & Fuente de la Higuera & Valencia & 41-B M \\
\hline Cy 74 & 2003 & Anna & Valencia & Tempranillo/41-B M \\
\hline Cy 75 & 2003 & Xàtiva & Valencia & Tempranillo/41-B M \\
\hline Cy 76 & 2003 & Anna & Valencia & $1103 \mathrm{P}$ \\
\hline Cy 77 & 2003 & Aielo de Malferit & Valencia & $161-49 \mathrm{C}$ \\
\hline Cy 78 & 2003 & Alfarrasí & Valencia & $1103 \mathrm{P}$ \\
\hline Cy 79 & 2003 & Albaida & Valencia & $140 \mathrm{Ru}$ \\
\hline Cy 81 & 2003 & Beneixama & Alicante & Tempranillo/161-49 C \\
\hline Cy 82 & 2003 & Xátiva & Valencia & Syrah/110 R \\
\hline Cy 83 & 2003 & Fontanares & Valencia & Tempranillo/161-49 C \\
\hline Cy 84 & 2003 & Aielo de Malferit & Valencia & $140 \mathrm{R}$ \\
\hline Сy 86 & 2004 & Mollina & Málaga & Pedro Ximénez/110 R \\
\hline Cy 92 & 2004 & Alcázar de San Juan & Ciudad Real & Cencibel/161-49 C \\
\hline Cy 95 & 2004 & Alcázar de San Juan & Toledo & Moscatel/Gravesac \\
\hline Cy 96 & 2004 & Lillo & Toledo & $1103 \mathrm{P}$ \\
\hline Су 98 & 2004 & Turís & Valencia & Monastrell/161-49 C \\
\hline Cy 101 & 2004 & Alesanco & La Rioja & Tempranillo/110 R \\
\hline Cy 102 & 2004 & Haro & La Rioja & Tempranillo/110 R \\
\hline Cy 103 & 2004 & Villar & Valencia & Merseguera/n/d \\
\hline Cy 104 & 2004 & Fuendejalón & Zaragoza & Cabernet Sauvignon/n/d \\
\hline Cy 105 & 2004 & Fuendejalón & Zaragoza & Merlot/110 R \\
\hline Cy 106 & 2004 & Almansa & Albacete & Tempranillo/n/d \\
\hline CBS 112609 & 1979 & $\mathrm{Al}$ & & Cabernet Sauvignon/n/d \\
\hline
\end{tabular}


Politécnica de Valencia-CSIC. Sequences were edited using the program DNAman (Version 4.03, Lynnon BioSoft, Quebec, Canada). Sequences were aligned using the distances were calculated using the $\mathrm{Ki}$ mura 2-parameter model. For phylogenetic inference, the neighbor-joining (NJ) method was used (27). The NJ tree and the statistical confidence of a particular group of sequences in the tree, evaluated by bootstrap test (1,000 pseudoreplicates), were performed using the computer program MEGA version 3.1 (17). Additional sequences of $C$. liriodendri from California (AY997601 and AY997602) and France (AY997587), and C. macrodidymum from California (AY997608 and AY997619) and Chile (AY997604) were obtained from GenBank and added to the alignment.

Pathogenicity. The pathogenicity of selected isolates (Cy 1, Cy 14, Cy 32, Cy 36, CLUSTAL W program (30). The genetic

Cy 58, and Cy 88) representative of species previously determined by phenotypical studies and BT phylogeny was evaluated. Isolates were grown on PDA for 1 month at $25^{\circ} \mathrm{C}$ prior to inoculation.

Inoculum was prepared for each isolate by flooding the agar surface with $10 \mathrm{ml}$ of sterile distilled water (SDW) and scraping with a spatula. The resulting spore suspension was filtered through two layers of cheesecloth. The filtrate was diluted with SDW and conidial concentration was adjusted with a hemacytometer to $10^{6}$ conidia per ml.

Eight-month-old dormant rooted cuttings of grapevine rootstock cv. $110 \mathrm{R}$ were used for pathogenicity tests. Before inoculation, roots were trimmed and disinfested by immersion for $2 \mathrm{~min}$ in a $1.5 \%$ sodium hypochlorite solution, and washed twice with SDW. For each Cylindrocarpon isolate, eight plants were inoculated by dipping their roots for $30 \mathrm{~min}$ in the conid-

Table 2. Parameters for factors 1 and 2 extracted from the multivariate factorial analysis

\begin{tabular}{lcc}
\hline Variables analyzed & Factor 1 & Factor 2 \\
\hline $\log _{10}$ conidia per ml & $0.809333^{\mathrm{z}}$ & -0.069914 \\
Daily growth rate at $5^{\circ} \mathrm{C}$ & $0.899077^{\mathrm{z}}$ & -0.248582 \\
Daily growth rate at $10^{\circ} \mathrm{C}$ & $0.913733^{\mathrm{z}}$ & -0.212563 \\
Daily growth rate at $15^{\circ} \mathrm{C}$ & 0.674998 & -0.234995 \\
Daily growth rate at $20^{\circ} \mathrm{C}$ & 0.241948 & -0.183932 \\
Daily growth rate at $25^{\circ} \mathrm{C}$ & -0.132501 & 0.044135 \\
Daily growth rate at $30^{\circ} \mathrm{C}$ & 0.505865 & 0.127111 \\
Length of microconidia & -0.734763 & 0.393431 \\
Width of microconidia & -0.733337 & 0.432814 \\
Length of one-septate macroconidia & -0.203174 & $0.804342^{\mathrm{z}}$ \\
Width of one-septate macroconidia & -0.152505 & $0.732897^{\mathrm{z}}$ \\
Length of two-septate macroconidia & -0.457782 & $0.730430^{\mathrm{z}}$ \\
Width of two-septate macroconidia & -0.071949 & $0.877877^{\mathrm{z}}$ \\
Length of three-septate macroconidia & -0.504006 & $0.654497^{\mathrm{z}}$ \\
Width of three-septate macroconidia & -0.123738 & $0.837912^{\mathrm{z}}$ \\
Diameter of chlamydospores & 0.435739 & 0.047171 \\
\hline
\end{tabular}

${ }^{\mathrm{z}}$ Main contributing variables for factors 1 and 2 .

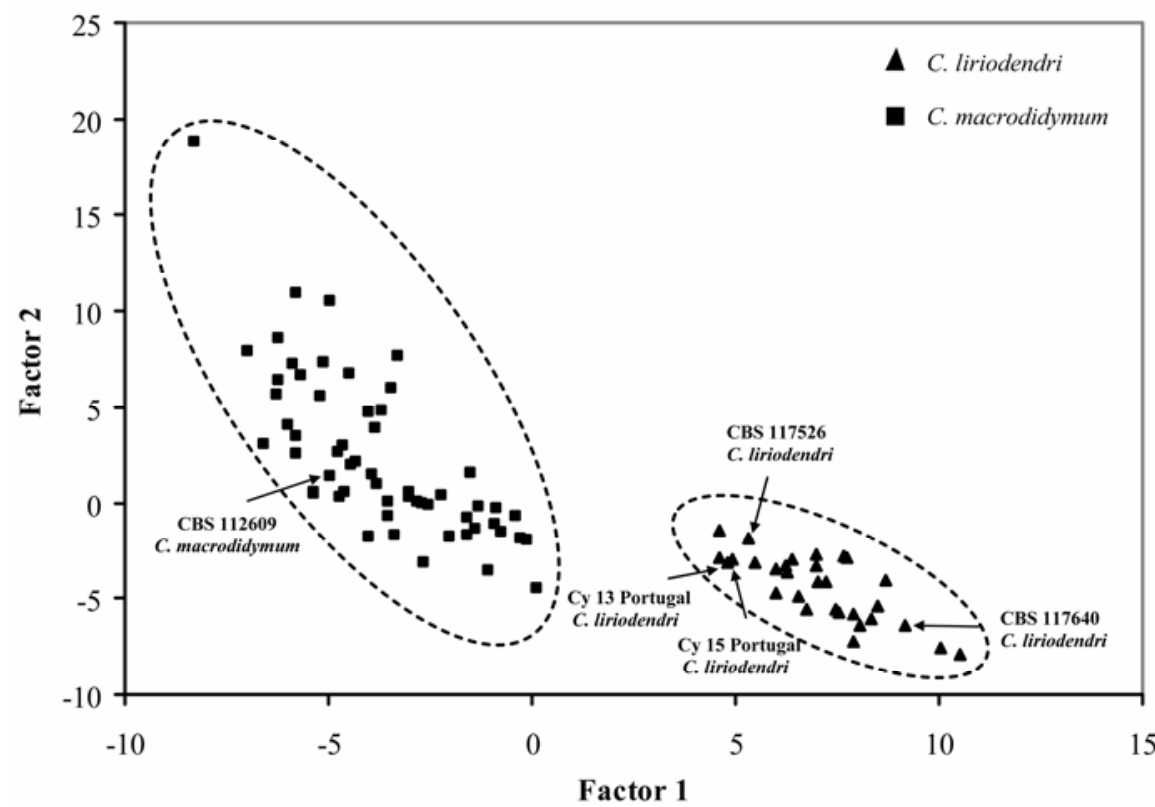

Fig. 1. Projection of Cylindrocarpon isolates on the plane of factors 1 and 2 from multivariate factorial analysis. ial suspension. Control plants were dipped in SDW. Rooted cuttings were then planted individually in 15-cm-diameter plastic pots containing sterilized peat moss and placed in a greenhouse at 25 to $30^{\circ} \mathrm{C}$ in a completely randomized design. One month later, each plant was drench inoculated with $40 \mathrm{ml}$ of the corresponding spore solution $\left(10^{6}\right.$ conidia per $\left.\mathrm{ml}\right)$ to guarantee root infection or SDW. After 4 months of incubation, all plants were gently uprooted and washed free of soil. Root symptoms of individual plants were evaluated on the following scale: $0=$ healthy with no lesions, $1=$ slight discoloration with 0 to $10 \%$ root mass reduction, $2=$ slight discoloration with 10 to $25 \%$ root mass reduction, 3 = moderate discoloration with 25 to $50 \%$ root mass reduction, $4=$ severe discoloration with $>50 \%$ root mass reduction, $5=$ dead plant. In addition, dry weights of shoot and root were recorded for each plant. Symptomatic roots were aseptically plated on MEAS to reisolate the fungus, as described above. Pathogenicity tests were conducted twice.

Root disease severity data were analyzed with the GENMOD procedure using the multinomial distribution and the cumulative logit as link function in SAS (SAS Institute Inc., Cary, NC, USA). Mean values were separated by chi-square test at $P$ $<0.05$. Analyses of variance (ANOVA) were conducted on root and shoot dry weights to determine the effects of different Cylindrocarpon isolates on grapevine rootstock cv. $110 \mathrm{R}$, using the Statgraphics Plus 5.1 software (Manugistics Inc., Rockville, MD, USA). Mean values were separated by Student's least significant difference test at $P<0.05$.

\section{RESULTS}

Phenotypical studies. Colony morphology on PDA was very heterogeneous. Aerial mycelium was floccose to felted, and the color varied from white to yellow or light to dark brown. Colony margins were entire, slightly lobulated, or lobulated. All isolates produced both microconidia and macroconidia, the latter having one to three septa, and chlamydospores, which were intercalary or terminal in the mycelium, single or occasionally in chains. The types of conidia and chlamydospores and their dimensions agreed with those described for the genus Cylindrocarpon $(4,28)$. Approximately $50 \%$ of the isolates had a buff reverse on $2 \%$ MEA, whereas $50 \%$ had an orange-dark brown reverse.

All isolates grew at temperatures of 5 , $10,15,20,25$, and $30^{\circ} \mathrm{C}$ but not at $35^{\circ} \mathrm{C}$. The optimal temperature was between 20 and $25^{\circ} \mathrm{C}$. The sporulation of the isolates also showed a broad range of variation (from 13.0 to $2.2 \times 10^{6}$ conidia per $\mathrm{ml}$ ).

In the multivariate factorial analysis of the phenotypical data, the two factors that presented the highest eigenvalues (7.03 and 2.28, respectively) were extracted. 
They accounted for approximately 58.3\% of the total variance (44.0 and $14.3 \%$ for factors 1 and 2 , respectively). The main contributing variables for factor 1 were $\log _{10}$ of conidia per $\mathrm{ml}$ and the daily growth rate at 5 and $10^{\circ} \mathrm{C}$, and the main contributing variables for factor 2 were the length and width of one-, two-, and threeseptate macroconidia (Table 2). The projection of all Cylindrocarpon isolates on the plane of factor 1 and 2 clearly separated them into two groups (Fig. 1). One of them clustered 56 of the Spanish Cylindrocarpon isolates and the reference isolate of C. macrodidymum, while the other clustered the remaining 26 Spanish Cylindrocarpon isolates and the four reference isolates of $C$. liriodendri. Mean and range values for these dominating phenotypical variables used to characterize both species among Spanish Cylindrocarpon isolates are listed in Table 3.

PCR, sequencing, and BT phylogeny. All Spanish and reference Cylindrocarpon isolates were amplified with the primers Dest 1 and Dest4. A PCR fragment of about $400 \mathrm{bp}$ was obtained for all of them.

Using PCR with the primers BT1a and BT1b, a fragment of about 520 bp was obtained for 56 of the Spanish isolates, and a fragment of about $470 \mathrm{bp}$ was obtained for the remaining 26 isolates. When sequences obtained from these PCR products were aligned using the CLUSTAL $\mathrm{W}$ program, a 52-bp insertion in the BT1 sequence was observed in those of greatest size.

Of the 423 nucleotides included in the BT1 phylogeny, 31 were variable. The NJ analysis identified two well-supported (100\%) clades (Fig. 2). One clade comprised the 56 Spanish Cylindrocarpon isolates with the 52-bp insertion, the reference isolate of $C$. macrodidymum, and the sequences of C. macrodidymum (AY997620, AY997619, AY997608, AY997604), all with quasi-similar sequences. The other clade comprised the other 26 Spanish $C y l$ indrocarpon isolates, the four reference isolates of $C$. liriodendri, and the sequences of $C$. liriodendri (AY997602, AY997587, AY997601), all with quasisimilar sequences.

Pathogenicity. Results of pathogenicity tests 4 months after plantation are shown in Table 4. A preliminary analysis of the data showed no significant trial-treatment interactions; therefore, the data from the two trials were combined. All Spanish Cylindrocarpon isolates tested were pathogenic to grapevine rootstock cv. 110 R. $P$ values indicated a significant effect of the isolates on root severity index $(P<$ $0.0001)$, root weight $(P=0.0003)$, and shoot weight $(P<0.0001)$. The root severity index ranged from 0.93 to 2.15 with a complete gradation among the isolates. All isolates significantly decreased the root and shoot dry weight, with the exception of isolate $\mathrm{Cy} 36$, from which the average shoot dry weight was not significantly different compared with the control. The isolates were reisolated from affected plants on MEAS as described above, confirming Koch's postulates.

\section{DISCUSSION}

This is the first study of a wide group of Cylindrocarpon isolates obtained from grapevine plants showing symptoms of black foot in grapevine nurseries and young vineyards in Spain. Based on the analysis of phenotypical characters and BT data, two species have been identified: $C$. liriodendri and $C$. macrodidymum. This result agrees with those obtained in South Africa and California, where these species have also been described as the main causal agents of black foot disease of grapevine $(14,15,22,23)$.

The species-specific primers Dest 1 and Dest 4 were designed by Hamelin et al. (16) to specifically detect $C$. destructans in the roots of conifer seedlings. In previous studies, Nascimento et al. (20) showed that these primers also amplified two other Cylindrocarpon species: C. liriodendri (previously identified as $C$. destructans) obtained from grapevines in Portugal (24) and $C$. obtusisporum obtained from grapevines in California. Here we confirmed that these primers also amplified all $C$. liriodendri and $C$. macrodidymum isolates nonspecifically. Thus, these primers are not useful to specifically recognize $C$. destructans.

Analysis of the BT1 sequence data, which has been used by other researchers to identify Cylindrocarpon species on grapevine $(14,22)$, allowed the identification of C. macrodidymum or C. liriodendri among the Spanish isolates. The existence of a 52-bp insertion in the BT1 sequence is considered to be a specific marker for $C$. macrodidymum (22). Here this insertion was found in the reference isolate for this species and 56 of the Spanish isolates, whereas it was not present in the reference isolates for $C$. liriodendri and the rest of the isolates (26 in total), which were identified as $C$. liriodendri. Moreover, the BT phylogeny grouped all the isolates of each species into two well-supported clades, which included the reference isolates and the additional sequences of $C$. macrodidymum and $C$. liriodendri. Strikingly, we found that Cylindrocarpon isolates of each species from diverse Spanish geographical origins and isolates from other origins including Australia, California, Chile, France, and Portugal had quasi-similar sequences.

In concordance with the published results obtained by other authors, phenotypical characteristics of the Spanish isolates were very variable $(14,22,24)$. Cylindrocarpon colonies showed different colors and textures. Conidial dimensions were also heterogeneous, and sporulation showed a broad range of variation. Thus, it was not possible to establish a clear concordance with these results and the description of each species. Halleen et al. (14) used the sizes of macroconidia to separate $C$. macrodidymum from $C$. liriodendri, indicating that the first produces larger and wider macroconidia than the second. Nevertheless, in our collection of Cylindrocarpon isolates this characteristic overlapped because some of the isolates, which were identified as $C$. macrodidymum, had lower mean dimensions of macroconidia than isolates identified as $C$. liriodendri. Petit and Gubler (22) noted that $C$. macrodidymum isolates produced relatively more chlamydospores than $C$. liriodendri, although they considered this characteristic too inconsistent to be used for identification purposes. These authors indicated that it is possible to differentiate C. liriodendri from C. macrodidymum on the basis of reverse color on 2\% MEA. $C$. liriodendri isolates had a buff reverse, whereas $C$. macrodidymum isolates had an

Table 3. Mean and range values for the main contributing phenotypical variables in the multivariate factorial analysis used to characterize Spanish isolates of Cylindrocarpon

\begin{tabular}{|c|c|c|}
\hline \multirow[b]{2}{*}{ Phenotypic characters } & \multicolumn{2}{|c|}{ Species $^{y, z}$} \\
\hline & C. liriodendri & C. macrodidymum \\
\hline $\log _{10}$ of conidia per $\mathrm{mL}$ & (5.3) $5.7(6.4)$ & (1.1) $3.5(5.5)$ \\
\hline \multicolumn{3}{|l|}{ Daily growth rate (mm) } \\
\hline $5^{\circ} \mathrm{C}$ & $(0.19) 0.32(0.46)$ & $(0.01) 0.06(0.12)$ \\
\hline $10^{\circ} \mathrm{C}$ & $(0.46) 0.72(0.81)$ & $(0.11) 0.28(0.50)$ \\
\hline \multicolumn{3}{|l|}{ Macroconidia $(\mu \mathrm{m})$} \\
\hline \multicolumn{3}{|l|}{ One-septate } \\
\hline Length & (11.6) 16.1 (21.6) & (12.7) $18.6(26.9)$ \\
\hline Width & (3.7) $4.4(5.0)$ & (3.8) $4.6(5.3)$ \\
\hline \multicolumn{3}{|l|}{ Two-septate } \\
\hline Length & (21.5) 23.4 (25.6) & (27.2) 30.5 (33.7) \\
\hline Width & (4.8) $5.0(5.3)$ & (5.0) $5.4(5.7)$ \\
\hline \multicolumn{3}{|l|}{ Three-septate } \\
\hline Length & (24.6) $27.5(29.7)$ & (33.1) $35.9(39.0)$ \\
\hline Width & (5.0) $5.3(5.6)$ & (5.5) $5.8(6.2)$ \\
\hline
\end{tabular}

${ }^{y}$ Species of Spanish isolates were determined by means of beta-tubulin analysis and multivariate factorial analysis of phenotypical data.

${ }^{\mathrm{z}}$ Values represent the mean of each phenotypic character (range-minimum and maximum-in parentheses). 


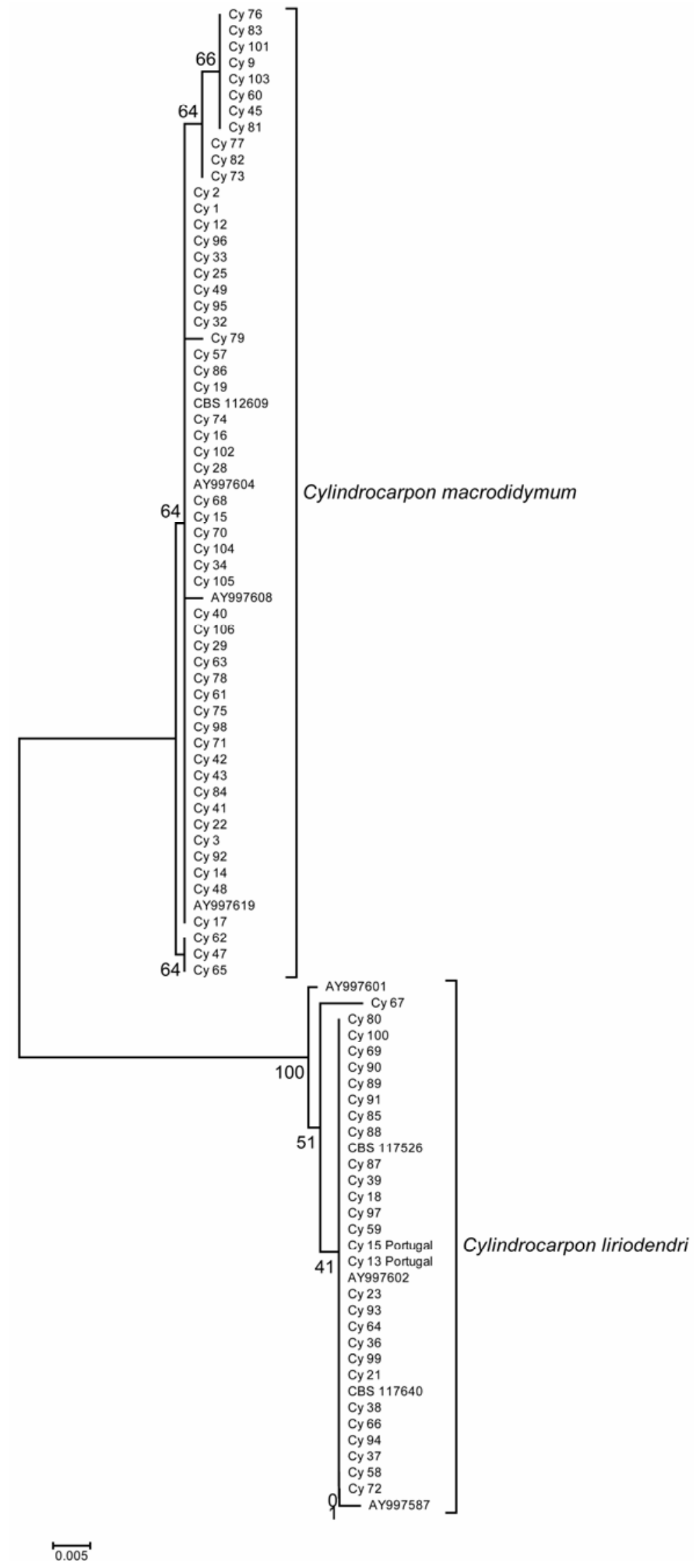

Fig. 2. Neighbor-joining phylogeny based on nucleotide divergences estimated according to the Kimura 2-parameter model from partial sequences of the beta-tubulin (BT) gene, BT1 of Cylindrocarpon isolates listed in Table 1, and additional sequences of $C$. liriodendri from California (AY997601 and AY997602) and France (AY997587), and C. macrodidymum from California (AY997608 and AY997619) and Chile (AY997604) obtained from GenBank. Numbers on nodes are the percent frequency with which a cluster appears in a bootstrap test of 1,000 runs. orange-dark brown reverse. Nevertheless, although both types of colors were observed when our isolates were grown on $2 \%$ MEA, they did not correspond with the species identification because they were produced both by $C$. liriodendri and $C$. macrodidymum isolates.

In our study, the phenotypical differentiation between both species was achieved by multivariate factorial analysis. The two factors selected in this analysis accounted for approximately $60 \%$ of the total variance. The projection of Spanish Cylindrocarpon isolates on the plane of these factors clearly clustered them into two groups of 56 and 26 isolates, which corresponded to the species $C$. macrodidymum and $C$. liriodendri, respectively. The species identification performed using this analysis coincided exactly with the results obtained with the study of the sequences of the BT1 gene. $\log _{10}$ of conidia per $\mathrm{ml}$, the daily growth rate at 5 and $10^{\circ} \mathrm{C}$, and the length and width of one-, two-, and three-septate macroconidia were the main contributing variables to separate both groups. Consequently, C. macrodidymum can be differentiated from $C$. liriodendri into a collection of isolates by producing fewer conidia, presenting longer and wider macroconidia, and lower growth rate at 5 and $10^{\circ} \mathrm{C}$.

Pathogenicity tests showed that Spanish isolates of both species were able to induce typical black foot disease symptoms and caused shoot and root mass reduction, confirming their pathogenicity to grapevine rootstock $\mathrm{cv} .110 \mathrm{R}$, in agreement with previous results $(14,22)$

C. obtusisporum has been one of the species associated in the past with black foot disease of grapevine. Nevertheless, in our study this species was not found among Spanish Cylindrocarpon isolates. Halleen et al. (14), who did not find this species, discussed the possibility that isolates previously identified as C. obtusisporum were in fact $C$. macrodidymum. Petit and Gubler (22) indicated that $C$. obtusisporum isolates described associated to black foot in California (29) also might be misidentified.

In conclusion, $C$. macrodidymum and $C$. liriodendri have been identified associated with young vines in Spain. C. macrodidymum is the predominating species, representing two-thirds of the studied isolates, although both Cylindrocarpon species are present in all grapevine growing regions in Spain. This is the first report of $C$. liriodendri and $C$. macrodidymum causing black foot disease of grapevine in Spain.

\section{ACKNOWLEDGMENTS}

Financial support is acknowledged from Projects AGL2003-02450/AGR and AGL2006-11884-C0401/AGR (Programa Nacional de Recursos y Tecnologías Agrarias, Ministerio de Educación y Ciencia, Spain). Sandra Alaniz was supported by a grant from the Agencia Española de Cooperación Internacional (AECI - Ministerio de Asuntos Exteriore y Cooperación, Spain). We thank Cecilia Rego 
Table 4. Pathogenicity of Spanish Cylindrocarpon isolates to grapevine rootstock cv. $110 \mathrm{R} 4$ months after plantation

\begin{tabular}{lccc}
\hline $\begin{array}{l}\text { Species } \\
\text { Isolate }\end{array}$ & $\begin{array}{c}\text { Root disease } \\
\text { severity }^{\mathbf{w}}\end{array}$ & $\begin{array}{c}\text { Root dry weight } \\
(\mathbf{g})\end{array}$ & $\begin{array}{c}\text { Shoot dry weight } \\
(\mathbf{g})\end{array}$ \\
\hline $\begin{array}{l}\text { C. liriodendri } \\
\text { Cy 36 }\end{array}$ & $1.20^{\mathrm{x}} \mathrm{a}^{\mathrm{y}}$ & $4.09 \mathrm{c}^{\mathrm{z}}$ & $11.21 \mathrm{~d}^{\mathrm{z}}$ \\
Cy 59 & $2.15 \mathrm{a}$ & $3.35 \mathrm{ab}$ & $9.20 \mathrm{bc}$ \\
Cy 88 & $1.27 \mathrm{a}$ & $4.09 \mathrm{c}$ & $9.85 \mathrm{bc}$ \\
C. macrodidymum & & & \\
Cy 1 & $1.50 \mathrm{a}$ & $3.63 \mathrm{abc}$ & $8.88 \mathrm{ab}$ \\
Cy 14 & $2.00 \mathrm{a}$ & $3.22 \mathrm{a}$ & $7.64 \mathrm{a}$ \\
Cy 32 & $0.93 \mathrm{a}$ & $4.07 \mathrm{bc}$ & $9.34 \mathrm{bc}$ \\
Control & $0.00 \mathrm{~b}$ & $4.92 \mathrm{~d}$ & $10.25 \mathrm{~cd}$ \\
\hline
\end{tabular}

${ }^{\mathrm{w}}$ Root symptoms were rated using the following scale: $0=$ healthy with no lesions, $1=$ slight discoloration with 0 to $10 \%$ root mass reduction, $2=$ slight discoloration with 10 to $25 \%$ root mass reduction, 3 = moderate discoloration with 25 to $50 \%$ root mass reduction, $4=$ severe discoloration with $>50 \%$ root mass reduction, $5=$ dead plant.

${ }^{x}$ Values represent the mean of 16 replications for each isolate.

${ }^{y}$ GENMOD. Means in a column followed by the same letter are not significantly different according to Chi-square test at $P<0.05$.

${ }^{z}$ ANOVA. Means in a column followed by the same letter are not significantly different according to Student's least significant difference test at $P<0.05$.

(Laboratório de Patologia Vegetal "Veríssimo de Almeida", Lisboa, Portugal) for providing reference isolates. We acknowledge J. M. Rodríguez Reina for their technical work.

\section{LITERATURE CITED}

1. Armengol, J., Vicent, A., Torné, L., GarcíaFigueres, F., and García-Jiménez, J. 2001. Fungi associated with esca and grapevine declines in Spain: A three-year survey. Phytopathol. Mediterr. 40:S325-329.

2. Aroca, A., García-Figueres, F., Bracamonte, L., Luque, J., and Raposo, R. 2006. A survey of trunk disease pathogens within rootstocks of grapevines in Spain. Eur. J. Plant Pathol. 115:195-202.

3. Auger, J., Esterio M., and Pérez, I. 2007. First report of black foot disease of grapevine caused by Cylindrocarpon macrodidymum in Chile. Plant Dis. 91:470.

4. Booth, C. D. 1966. The genus Cylindrocarpon. Mycol. Pap. (CMI) 104:1-56.

5. Dhingra, O. D., and Sinclair, J. B. 1995. Basic Plant Pathology Methods. 2nd ed. CRC Press, Boca Raton, FL.

6. Edwards, J., and Pascoe, I. G. 2004. Occurrence of Phaeomoniella chlamydospora and Pheoacremonium aleophilum associated with Petri disease and esca in Australian grapevines. Australas. Plant Pathol. 33:273-279.

7. Fisher, M., and Kassemeyer, H. H. 2003. Fungi associated with Esca disease of grapevine in Germany. Vitis 42:109-116.

8. Garrido, L. R., Sônego, O. R., and Urben, A. F. 2004. Cylindrocarpon destructans causador do
"Pé-Preto" da videira no Rio Grande do Sul. Fitopatol. Bras. 29:548-550.

9. Gatica, M., Césari, C., Magnin, S., and Dupont, J. 2001. Pheoacremonium species and Phaeomoniella chlamydospora in vines showing "hoja de malvón" and young vine decline symptoms in Argentina. Phytopathol. Mediterr. 40:S317-324.

10. Giménez-Jaime, A., Aroca, A., Raposo, R., García-Jiménez, J., and Armengol, J. 2006. Occurrence of fungal pathogens associated with grapevine nurseries and the decline of young vines in Spain. J. Phytopathol. 154:598602.

11. Grasso, S. 1984. Infezioni di Fusarium oxysporum e di Cylindrocarpon destructans associate a una moria di giovani piante di vite in Sicilia. Inform. Fitopatol. 1:59-63.

12. Grasso, S., and Magnano Di San Lio, G. 1975. Infezioni di Cylindrocarpon obtusisporum su piante di vite in Sicilia. Vitis 14:38-39.

13. Halleen, F., Fourie, P. H., and Crous, P. W. 2006. A review of black foot disease of grapevine. Phytopathol. Mediterr. 45:S55-67.

14. Halleen, F., Schroers, H. J., Groenewald, J. Z., and Crous, P. W. 2004. Novel species of Cylindrocarpon (Neonectria) and Campylocarpon gen. nov. associated with black foot disease of grapevines (Vitis spp.). Stud. Mycol. 50:431455.

15. Halleen, F., Schroers, H. J., Groenewald, J. Z., Rego, C., Oliveira, H., and Crous, P. W. 2006. Neonectria liriodendri sp. nov., the main causal agent of black foot disease of grapevine. Stud. Mycol. 55:227-234.
16. Hamelin, R. C., Bérubé, P., Gignac, M., and Bourassa, M. 1996. Identification of root rot fungi in nursery seedling by nested multiplex PCR. Appl. Environ. Microbiol. 62:4026-4031.

17. Kumar, S., Tamura, K., and Nei, M. 2004. MEGA 3: Integrated software for molecular evolutionary genetics analysis and sequence alignment. Brief. Bioinform. 5:150-163.

18. MacDonald, J. D., and Butler, E. E. 1981 Cylindrocarpon root rot of tulip poplar. Plant Dis. 65:154-157.

19. Maluta, D. R., and Larignon, P. 1991. Piednoir: mieux vaut prévenir. Viticulture 11:71-72.

20. Nascimento, T., Rego, C., and Oliveira, H. 2001. Detection of Cylindrocarpon black-foot pathogens in grapevine by nested PCR. Phytopathol. Mediterr. 40:S357-361.

21. Peña, D. 2002. Análisis de datos multivariantes. Mc Graw Hill, Madrid.

22. Petit, E., and Gubler, W. D. 2005. Characterization of Cylindrocarpon species, the cause of black foot disease of grapevine in California Plant Dis. 89:1051-1059.

23. Petit, E., and Gubler, W. D. 2007. First report of Cylindrocarpon liriodendri causing black foot disease in California. Plant Dis. 91:1060.

24. Rego, C., Nascimento, T., and Oliveira, H. 2001. Characterization of Cylindrocarpon destructans isolates from grapevines in Portugal. Phytopathol. Mediterr. 40:S343-350.

25. Rego, C., Oliveira, H., Carvalho, A., and Phillips, A. 2000. Involvement of Phaeoacremonium spp. and Cylindrocarpon destructans whith grapevine decline in Portugal. Phytopathol. Mediterr. 39:76-79.

26. Rumbos, I., and Rumbou, A. 2001. Fungi associated with esca and young grapevine decline in Greece. Phytopathol. Mediterr. 40:S330-335.

27. Saitou, N., and Nei, M. 1987. The neighborjoining method: A new method for reconstruc tion phylogenetic trees. Mol. Biol. Evol. 4:406-425.

28. Samuels, G. J., and Brayford, D. 1990. Variation in Nectria radicicola and its anamorph, Cylindrocarpon destructans. Mycol. Res. 94:433-442

29. Scheck, H. J., Vasquez, S. J., and Gubler, W. D. 1998. First report of black-foot disease, caused by Cylindrocarpon obtusisporum, of grapevine in California. Plant Dis. 82:448.

30. Thompson, J. D., Higgins, D. G., and Gibson, T. J. 1994. CLUSTAL W: Improving the sensi tivity of progressive multiple sequence alignment through sequence weighting, positionspecific gap penalties and weight matrix choice. Nucleic Acids Res. 22:4673-4680.

31. Whiting, E. C., Khan, A., and Gubler, W. D. 2001. Effect of temperature and water potential on survival and mycelial growth of Phaeomoniella chlamydospora and Phaeoacremonium spp. Plant Dis. 85:195-201. 